\title{
Язык и власть: «новый новояз» постсоветского периода*
}

\author{
NAM HYE HYUN \\ Yonsei University 50, Yonsei-ro, Seodaemun-gu, Seoul, 120-749 Republic of Korea \\ E-mail: zean01@yonsei.ac.kr
}

(Received: 21 July 2017; accepted: 14 September 2017)

\begin{abstract}
Newspeak as a language of political manipulation is an indispensable attribute not only of the Soviet political language (novojaz) but also of the language of politics as such. And in a certain sense, any normal language can contain some elements of newspeak because the regulatory function is peculiar to a language. This paper is dedicated to the continuity of Soviet and post-Soviet political discourse, in particular, the reproduction of rhetorical devices of Soviet novojaz in modern Russian political discourse.
\end{abstract}

Keywords: language of politics, totalitarian language, newspeak, novojaz, ritualization, desemantization

\section{1. Введение}

Язык нельзя рассматривать в отрыве от его носителей. Данный тезис особенно значим в русской истории, где прослеживается довольно тесная связь языка с властью, политикой и идентичностью (GASPAROV 2004). Петр Первый счел важнейшей задачей модернизации России активное внедрение научных, технических и торговых терминов из европейских языков и упразднение старых церковнославянских букв (Живов 1996: 69-154). Также известные споры А. С. Шишкова и Н. М. Карамзина о модели создания русского литературного языка в начале XIX века происходили на фоне обсуждения идентичности Российского государства (ЛотмАН-У СпЕнский 1975).

Особенно уникальную роль языка подчеркивают по отношению к Советской России. После Октябрьской революции язык стал важнейшим фундаментом строительства советского государства и «воспитания» его граждан. По этому поводу А. Б. Григорьев пишет: «Мысль о всевластии языка, как нигде, важна в применении к нашей стране, имеющей опыт тоталитаризма с его двумя страшными орудиями господства и принуждения - языком (тотальной, всепроникающей пропаганды) и террором» (ГРигорьев 1998: 372).

В связи с этим данная статья посвящается вопросу связи языка с властью, манипулированием в советском и в постсоветском политическом дискурсе.

* This work was supported by the Ministry of Education of the Republic of Korea and the National Research Foundation of Korea (NRF-2015S1A5B5A07041336). 
На Западе проблемы языка и власти, языка и идеологии, языкового манипулирования, роли мифа в политической коммуникации достаточно давно находились в фокусе исследовательского внимания, а в России ими стали интересоваться преимущественно с начала перестройки (ШЕйгАл 2005). ${ }^{1}$

Появились исследования, осмысляющие языковое существование в тоталитарном прошлом, и также активно анализируются изменения языка, происходившие в новых политических и общественных условиях. Особенно много работ по политической лингвистике посвящаются выявлению языковых дифференциальностей, связанных с политическими переменами в России. В данной же статье в фокусе оказываются прежде всего соотносительность, преемственность политического дискурса в советской и постсоветской России, т. е. воспроизведение новояза в современном политическом дискурсе.

Как известно, в советское время язык рассматривался в качестве важного идеологического инструмента и средства разрушения старых норм и создания нового порядка. Следовательно, употребление языка особенно в официальной сфере полностью регулировалось требованиями советского языкового стандарта, в результате чего сложилась устойчивая система норм, охватывающая все уровни русского языка. Этот новый язык тоталитарного общества получил название «советский новояз». ${ }^{2}$ Главные его цели - манипуляция сознанием пользователей, сокрытие реальности и затем создание иллюзорной реальности. Эти цели достигались различными путями, например, широким использованием скользких эвфемизмов, затасканных идиом, эксплуатацией понятий, не имеющих предметного значения, обилием аббревиатур и т. д.

Как мы попытаемся показать ниже, после низвержения тоталитаризма и с провозглашением демократии специфические черты новояза продолжают присутствовать и в современном политическом дискурсе, лексика и фразеология которого во многом напоминают лексику и фразеологию советского новояза (ВАСиЛЬЕВ 2000). Дело дошло до того, что филологи и интеллигенты многократно выражали опасение по поводу возвращения советского новояза или появления «постновояза» в современном российском обществе. ${ }^{3}$ Однако данный феномен часто упускается из виду исследователями или же отмечается лишь в употреблении типичных советизмов и советских прецедентных текстов (Пихурова 2005, РезАновА 2008, ГоломидовА 2009 и т. д.).

${ }^{1}$ Политический дискурс - это класс жанров, ограниченный социальной сферой, а именно политикой. Правительственные обсуждения, парламентские дебаты, партийные программы, речи политиков - это те жанры, которые принадлежат сфере политики. Значит, политический дискурс - это дискурс политиков.

${ }^{2}$ Для его обозначения применяются разные термины: «советский язык», «тоталитарный язык советской эпохи», «язык советского общества», «советский вариант русского языка», «русский советский язык», «казенный язык», «ритуальный язык», «деревянный язык», «язык лжи», «ложный язык», «жаргон власти» и др.

${ }^{3}$ См. статьи, интервью и заметки критически мыслящей интеллигенции по поводу возвращения советского новояза: http://www.svoboda.mobi/a/1730479.html; http://tumasoff.blogspot. kr/2008/12/blog-post_13.html; http://ejnew.com/?a=note\&id=8685; http://www.utro.ru/articles/2006/ 11/03/598409.shtml. 
В настоящей статье мы будем рассматривать схожесть советского новояза и постновояза не только в употреблении советизмов и советских претедентных текстов, но и в активизации специфических приемов новояза, таких как эвфемистическая риторика, ритуализация языка, десемантизация, аббревиатуры и т. д. Поскольку преемственность советского и постсоветского политического дискурса очень широка, этот аспект нуждается в более объемном анализе, здесь же мы ограничимся лишь в представлении общей картины данной проблематики. ${ }^{4}$

Итак, ниже во второй части статьи вкратце перечисляются наиболее характерные черты новояза. В третьей части прорисовываются некоторые проявления новояза в современном политическом дискурсе. В четвертой части будут представлены выводы.

\section{2. Воплощение новояза в советское время}

Как известно, новояз - это калька с английского слова newspeak, появившегося в романе-антиутопии Джорджа Оруэлла «1984», изданном в 1948 г. ${ }^{5}$ В романе новоязом называется язык тоталитарного общества, искаженного партийной идеологией и бюрократическими оборотами. Как автор объясняет в эссе «О новоязе», включенном в сам роман, новояз был разработан для того, чтобы сделать невозможными любые иные течения мысли, и это достигалось не столько изобретением новых слов, сколько путем исключения нежелательных слов и очищения оставшихся слов от неортодоксальных значений (см. Оруэлл 1989: 200-201). Именно поэтому новояз описывается как единственный на свете язык, чей словарь с каждым годом сокращается. Моделью для построения этого языка послужили официальные документы тоталитарных режимов Третьего рейха и сталинского СССР.

Сегодня определение новояза как термина весьма расплывчато. Обычно выделяют два вида: новояз как политический подъязык и новояз как подъязык определенных субкультур. В первом смысле он обозначает язык власти, пропаганды, идеологии тоталитарного общества, в частности, Советского Союза. А во втором значении новояз представляет собой жаргон определенной субкультуры, чаще всего, язык участников интернет-коммуникации или «язык падонков». В обоих случаях новояз представляет разновидность языка, образованную путем преднамеренного искажения слов литературного языка. В рамках нашей статьи ограничимся первым смыслом этого термина.

\footnotetext{
${ }^{4}$ Подобная попытка уже была сделана на материале других языков бывшего тоталитарного языка. Например, Р. Василев показывает, как наследие тоталитарного прецендента воспроизводится на современном болгарском языке посттоталитарной эпохи (VASSILEV 2011).

${ }^{5}$ Перевод романа «1984» на русский был сделан В. Голышевым в середине 1980-х гг., однако уже до публикации перевода В. Голышева образованными носителями русского языка использовалось слово новояз. См. еще однотипные переводы слова newspeak на другие языки: новогор (болг.), навамоуе (белорус.), nowomowa (пол.), Newsprech, Neusprache (нем.), novlangue (франц.), neolengua, nuevahabla (исп.), neolingua (итал.) (об этом см. КрОНГАуз 2016: 234-236).
} 
В работах по советскому новоязу к наиболее ярким его чертам относятся следующие: высокая степень клишированности, эвфемистичность, ритуализация речевой деятельности, десемантизация языковых единиц (BRoŃSKI 1979, SÉRIOT 1985, ЗЕМСКАЯ 1996a, ЗЕМСКАЯ 1996b, GŁOWIŃSKI 1991, ВЕЖБИЦКАЯ 1993, КуПина 1995, Романенко 2000, НАм 2014а). Все они призваны замаскировать и скрыть реальное положение вещей. ${ }^{6}$

Перед тем, как рассмотреть каждый из указанных признаков подробнее, сразу же оговоримся, что любому языку власти присущи агитационность, пропагандичность, лозунговость и идеологизация всех сторон жизни, так как именно посредством языка власть стремится создать псевдореальность и иллюзорную действительность (МихеЕв 1991: 131). Поэтому вышеперечисленные признаки можно найти не только в советском новоязе, но и в любом другом политическом дискурсе, но, безусловно, в различной степени их проявления. $^{7}$ Как нам представляется, именно в советском новоязе они проявляются в большей степени в силу политической ситуации в СССР, где социализм, строившийся в течение 70 лет, как метко отметил Б. Ю. Норман, в значительной мере был социализмом на бумаге и обслуживался огромным количеством слов, за которыми в реальной жизни ничего не стояло (либо стояла их полная противоположность) (НормАн 1994: 55-56). В связи с этим О. Лейбович утверждает, что мир социализма - это застывшие слова, управляющие людьми (ЛЕйБович 1998: 93).

\section{1. Эвфемистичность}

Эвфемизмы - слова и выражения, смягчающие грубый смысл речи. Эвфемистичность речи объясняется стремлением автора притупить критическую остроту высказывания при описании негативных явлений жизни (см. КУЗИНА-МАЛЕРВЕЙН 2007: 19). Если вспомнить, что одна из функций новояза заключается в завуалировании реальности и создании иллюзорного мира, то

${ }^{6}$ В данной статье не рассматривается историческое формирование новояза. По мнению Н. А. Бердяева, начальную стадию развития новояза можно проследить в подпольной мыслеречевой деятельности российской интеллигенции XIX в., которая закономерно превратилась в бурный поток советского дискурса (БЕРдяев 1990). Д. Вайсс считает, что корни советского новояза можно искать в пролетарских песнях таких, как «Варшавянка» (http://nashagazeta.ch/ news/15216). На наш взгляд, на создание советского политического выверенного языка также повлияла борьба за унификацию речи, против ярких вербальных проявлений человеческой индивидуальности, ужесточенная в послевоенный период с 1940-х гг. (НАм 2014а, НАм 2015).

${ }^{7}$ Отвечая на вопрос, насколько черты новояза были новыми для русского языка, В. А. Чудинов констатирует, что многие приемы, использованные при конструировании новояза, являются естественными для некоторых языков. Например, использование сложносокращенных слов характерно для русского и немецкого, словообразование путем добавления к слову префиксов и суффиксов - для агглютинативных языков и т. д. Однако образование эвфемизмов само по себе не может служить признаком новояза, так как оно является естественным языковым процессом (http://chudinov.ru/oruell/1/). Что касается ритуальности, как мы убедимся дальше, она свойственна не только советскому новоязу, но и вообще политической коммуникации с фиксированной формой и без установки на новизну содержания. 
можно понять, почему эвфемистичность является характерным явлением этого языка. Например, в советское время: взял 'украл', дал 'дал взятку', приписал 'обманул государство', сорвался (с работь) 'прогулял', отписался (в ответ на претензию) 'проявил бюрократизм' (БурлАцкий 1988: 8). См. еще другие примеры: изолятор 'тюрьма', проработка 'грубая критика', компетентные органы 'органы государственной безопасности', вышка 'расстрел', для служебного пользования 'о секретных документах', вести себя нескромно 'о коррупционере' и т. П. Продуктивными эвфемизмами этого времени были и слова недочеть, недовес, недосбор вместо ошибки, воровство, разгильдяйство, халатность. Также показательно использование слов с диффузной семантикой, в частности, неопределенных местоимений типа некотоpыı̆, кто-то, кое-кто, например: «Если кто-то кое-где у нас порой честно жить не хочет...» (фраза известной советской песни).

По поводу советских эвфемизмов Г. О. Винокур писал: «Штампованная фразеология закрывает нам глаза на подлинную природу вещей и их отношений... Поскольку мы пользуемся ничего не значащими лозунгами и выражениями, то бессмысленным, ничего не значащим становится и наше мышление» (Винокур 1925: 84-86).

Эвфемистичность проявляется не только на уровне лексики, но и на уровне синтаксической конструкции. С целью маскировки истинного положения дел широко употреблялись и предложения с абстрактными существительными в роли подлежащего, и безличные конструкции, отстраняющие субъект действия. В результате употребления таких конструкций происходит устранение реального субъекта, и затем дальнейшие идеологические манипуляции с поименованными сущностями.

(1) Сколько раз, например, говорилось, что огромное количество металла расходуется у нас нерационально? (Из газет 1960-х).

(2) Переход от прапрадедовской формы хозяйствования к формам соичиалистического развития промылленности на базе ее индустриализации по последнему слову техники, а также развития земледелия и скотдоводства на базе крупного совхозного и колхозного хозяйства, является легким делом («Полярная звезда», 22.05.1930).

\section{2. Аббревиатура}

Изобилие аббревиатур и большое количество сложных слов было одним из советских языковых нововведений, повлекших за собой долговременные тяжкие лингвокультурные последствия, например: Ревком, ликбез, рабфак, Коминтерн, «Самиздат», «Тамиздат», угрозыск, главсахар, главбумага, главтабак. Многочисленны были названия синдикатов: Pocmon, Продаруд, Продамет, Лензото и др.

А почему в советское время появлялось столь много аббревиатур? Дело в том, что сокращение значимых корней затемняет их первоначальный смысл и придает слову нужное идеологическое содержание. Однако расшифровка 
аббревиатур порой доходит до абсурда, что формирует эзотеричность, т. е. подлинный их смысл понятен лишь немногим, например: Мособлжилуправление 'Московское областное управление жилищного хозяйства', Мосремэлектробытприбор 'Московский завод по ремонту электробытовых приборов', Союзглавиветметуглекомплект 'Главное управление по комплектованию предприятий цветной металлургии и угольной промышленности Госснаба СССР'.

\section{3. Десемантизация}

Новояз был изобретен прежде всего для манипуляции сознанием его пользователей. Поэтому многие слова в нем теряли свое первоначальное значение и приобретали новое, предусмотренное властью значение. К ним относятся такие, как мир, равенство, братство, разоружение, соииальная справедливость или слуги народа. Затем эти слова в жестких конструкциях превращались в клише. Эти идеологические клише, которыми был насыщен советский новояз, ориентированы либо на абстрактный, условный референт, либо на референт, отсутствующий в действительности (ЗЕмсКАЯ 1996b: 23), например: «Народ и партия едины»; «Экономика должна быть экономной»; «Союз нерушимый республик свободных»; «Партия - ум, честь и совесть нашей эпохи»; «Коммунизм - это есть советская власть плюс электрификация всей страны» и т. д.

Такие слова и обороты Б. Ю. Норман называет «лексическими фантомами». Он объясняет, что эти лексические фантомы, лишенные предметного значения, возникают, когда отрыв слова от денотата обусловлен идеологической деятельностью человека, разработкой той или иной социальной утопии, поддерживанием определенных социальных иллюзий (НоРмАН 1994: 55-56, НОРМАН 2006: 19).

\section{4. Ритуальность}

В публичном политическом дискурсе советской эпохи существовали особые правила политической коммуникации как ритуала: всем посвященным было известно, кто, что, когда и в какой форме должен сказать, а также, кто и как должен отреагировать на слова выступающего, т. е. бурные аплодисменты, просто аплодисменты, выступления в прениях, последующая организация собраний для выражения поддержки и др. (Чудинов 2006: 53). Типичный пример советской ритуальной коммуникации - партийные съезды или сессии Верховного Совета. Там каждый ход коммуникации был заранее тщательно спланирован, и делегаты и депутаты превращались в участников

\footnotetext{
${ }^{8}$ Подобное словотворчество повлияло и на образование новых оригинальных имен в советское время, например: Ноябрина, Тракторина, Владлен, Агитпроп, Велиор, Даздраперма, Донэра, Исталина, Индустрина, Лениниана, Марэнленст, Пятвчет, Товарищтай, Электрификаичия и др.
} 
грандиозного спектакля. Выступления начинались с обращения типа товарищи, граждане и цитат из наследия «великих вождей». В этом можно заметить ритуальность, или даже театральность политического языка.

Такая ритуальность языка характерна для коммуникации с фиксированной формой и без установки на новизну информации. Ритуальная коммуникация наиболее ярко проявляется в религиозной сфере. Не зря Н. А. Бердяев писал, что большевизм - это лже-религия и потому преследует все религии как конкурентов (БЕрдяев 1990: 29). ${ }^{9}$ Философ Б. Рассел тоже указывал на то, что марксизм и большевизм - это полноценная религия.

В связи с этим публичные речевые действия в советское время воспринимались как некая ритуализованная деятельность. А для проведения ритуала в зрелом социалистическом обществе уже не требовался обыденный русский язык, он даже в какой-то степени мешал ритуальным действиям (см. КронгАуз 2016: 80). Следствием непригодности нормального языка для осуществления ритуала является появление новояза. Иными словами, в советский период в официальной сфере общения употреблялся новояз как высокий язык, в то же время в неофициальной сфере продолжал существовать собственно «русский язык». Тем самым в советское время формировалась своего рода диглоссия. ${ }^{10}$

Советский новояз как высокий ритуальный язык претендовал на абсолютную истину, поэтому в нем превалировали триумфализм, лозунговость и монологичность. См. пример, взятый у М. В. Горбаневского:

(3) XXIV съезд КПСС, 31 марта 1971 г., речь товарища А. В. Смирновой (ткачиха Яковлевского льнокомбината Ивановской области): Все выступавшие до меня с этой трибуны горячо одобряли неутомимую преобразовательную деятельность Центрального комитета партии. Вот и я счастлива сказать свое сердечное слово. Высокая должность ткачихи побуждает меня сделать

${ }^{9}$ В связи с этим интересно привести цитату М. В. Горбаневского: «Большевикам же было важно сакрализовать своих героев... В сознание масс и была внедрена схема: вместо поклонения святым мощам - вот вам мощи, которые до сих пор лежат на Красной площади; вместо икон - пожалуйста, портреты вождей; вместо крестных ходов - манифестации; вместо литургии и псалмов - партсобрание и „Интернационал“. Большевики поступили очень хитро: сакрализовали свои лозунги» (ГОРБАНЕВСКИй 2009b).

${ }^{10} \mathrm{~B}$ связи с этим можно поставить вопрос о статусе новояза. Многие ученые квалифицируют его в качестве подъязыка или социолекта. Например, Э. И. Хан-Пира убеждает, что новояз не может быть назван языком в лингвистическом значении этого слова, так как он не имеет собственной фонетической и грамматической системы. По его мнению, новояз скорее лексико-семантическая система, социолект, классовый жаргон (ХАН-ПиРА 1994: 16-17). Для характеристики новояза М. Гловиньский предлагает термин «квазиязык». На основе наблюдения над языковой ситуацией в Польше он считает, что хотя nowomowa родилась в политической публицистике и приобрела черты функционального стиля, однако она претендовала на универсальность, стремясь подчинить себе другие сферы языка как образец более широкого общения (GŁOWIŃSKI 1991: 9-10). Присоединяясь к вышеупомянутым позициям, мы характеризуем новояз как политический социолект, хотя, в отличие от всех прочих социолектов, новояз охватывал довольно широкую сферу употребления, проникая в официально-деловой и научный стили литературного языка. 
одно профессиональное сравнение: наша партия как опытный ткач день за днем ткет прочное полотно нового общества, имя которому - коммунизм. (Аплодисменты) Нынешний советский рабочий - подлинный хозяин страны u творец, активно участвующий в управлении производством, как справедливо говорил в своем докладе Леонид Ильич Брежнев. Советский рабочий образован и воспитан. Труд для него не только источник заработка, но и могучее средство приобщения к светлому товариществу, созидающему самый справедливый общественный строй на земле. Это большое счастье быть частицей советского рабочего класса! И хочется высказать большую сердечную благодарность ленинскому Центральному комитету нашей партии за высокую оценку роли рабочего класса, которую дал в отчетном докладе Леонид Ильич Брежнев. (Аплодисменты) (ГорБАнЕВский 2009а: 6).

Итак, тоталитарный язык был перегружен идеологическими штампами, лозунгами, на базе которых формировались мифы тоталитарной эпохи. Описанная высокая степень эвфемистичности, клишированности и аббревиатур приводит к десемантизации, так как эти явления в языке подразумевают под собой искажение, завуалирование первоначального смысла. А десемантичность языковых единиц является необходимым условием формирования ритуальности коммуникации, поскольку последняя минимально информативна; ср. как эвфемизмы, десемантичные единицы служат ритуализации речи в примере (3).

\section{3. «Постновояз» в постсоветской России}

Как известно, после падения советского режима Россия шла по сложному пути от социализма к капитализму, от забытья к воспоминаниям, от демифологизации к ремифологизации (НАм 2014b: 87). Разнонаправленные отношения к советскости и советским символикам, конфликты вокруг них действительно прослеживаются и в употреблении языка.

С одной стороны, наблюдается быстрый уход в пассив большого количества слов, связанных с советскими временами. Безусловно, самые яркие изменения языка в рамках десоветизации произошли на лексическом уровне. За короткий срок с лексики снята идеологическая окраска, и целые пласты лексики эпохи социализма ушли в пассив. К десоветизации можно отнести еще и доминирование устной, диалогичной речи над письменной, монологичной. Об этом уже много было сказано в ряде научных работ (ДАнн 2009, Крысин 2008, НАм 2011). ${ }^{11}$

С другой стороны, в русском языке еще остаются следы советского новояза. Особенно в современном политическом дискурсе для манипулятивной

${ }^{11}$ По поводу состояния современного русского языка Д. Вайсс высказал интересную мысль. Он полагает, что современный русский язык можно представить как триаду: язык литературный, язык советский и уголовная «феня». Последняя уже вошла в разговорную речь и в речь политиков, пытающихся достичь речевой сближенности с народом. Достаточно вспомнить знаменитое путинское мочить в сортире (http://nashagazeta.ch/news/15216). 
функции активно используются приемы советской пропагандистской риторики. ${ }^{12}$ Некоторые филологи указывают на первые признаки возврата к советскому языку уже в конце правления Б. Н. Ельцина и в начале правления В. В. Путина. По их мнению, к разряду новоязовской лексики XXI века можно отнести прежде всего выражения вертикаль власти и суверенная демократия, которые маскируют авторитаризм, диктатуру. Каждое слово в них вполне осмысленно, но словосочетание в целом не имеет никакого смысла, и поэтому они считаются своеобразным мостиком от советского новояза к новому новоязу (ГоРБАНЕВСКИй 2009а: 10). Для обозначения последнего предлагается термин «Постновояз» (ВАсиЛЬЕв 2000).

В целях наглядности соотносительности советского новояза с постновоязом приведем два примера из работы М. В. Горбаневского. Один принадлежит эпохе брежневского развитого социализма, а другой относится к временам современной России:

(4) XXV съезд КПСС, 26 февраля 1976 г., речь товарища А. Ф. Ерофеевой (прядильщица Ивановского меланжевого комбината им. К. И. Фролова): «Леонид Ильич Брежнев сердечно поздравил наш коллектив с этой трудовой победой. Если бы вы, дорогой Леонид Ильич, могли видеть, каким источником нового вдохновения стало ваше приветствие, и не только на нашем комбинате, но и на всех предприятиях области!.. Мы, рабочие, горячо одобряем, когда Центральный комитет КПСС, Совет министров СССР направляют приветствие трудовым коллективам и отдельным передовикам. Нас восхищает, как тонко Центральный комитет и советское правительство чувствуют особенность работы коллективов, как верно находят те единственно правильные и нужные, полные глубокого уважения к рабочему человеку слова, которые зовут нас к новым трудовым победам» (ГоРБАНЕВский 2009а).

(5) VIII съезд партии «Единая Россия», 1 октября 2007 г., речь товарища Е. Н. Лапшиной (ткачиха Родниковской текстильной фабрики Ивановской области): «Годы вашего президентства, уважаемый Владимир Владимирович, стали временем перемен к лучшему для очень многих. И для таких простых рабочих людей, как я, и для таких сельских тружеников, как мои родители. (Аплодисменты) Спасибо. И мы бы, конечно, хотели, чтобы эти перемены к лучшему продолжались и дальше. При этом при всем, к сожалению, мы не уверены, что и дальше все будет меняться к лучшему, потому что вы, Владимир Владимирович, отказались выдвигаться на третий президентский срок. И я вот вижу на этом съезде так много больших начальников и просто умных людей. Я обращаюсь ко всем вам: давайте вместе что-нибудь придумаем, чтобы Владимир Владимирович Путин оставался нашим президентом и после восьмого года...» (ГоРБАНЕВский 2009а).

${ }^{12}$ В последнее время в русском языке в целом имеет место активное воспроизведение советских вербальных маркеров. Особенно в рекламных текстах и коммерческой номинации наблюдается ностальгическое употребление советских прецедентных текстов (НАм 2014b: 90), ср., например, кафе «Правда», рестораны «Зов Ильича», «Столичный» и «Советский Союз», «Квартира 44», «Столовая № 57» и др. 
В обоих текстах присутствует пропагандистский триумфализм, лозунговость и безапелляционность. Ниже рассмотрим, как конкретные новоязовские черты, такие как высокая степень эвфемистичности, десемантизация языковых единиц и ритуализация речевых актов воспроизводятся в современном политическом дискурсе.

\section{1.Эвфемистичность}

Постновояз не менее, чем советский новояз прибегает к эвфемизмам. Казнокрадство именуется нечелевым расходованием бюджетных средств, две чеченские кампании - контртеррористической операцией и восстановлением конституционного строя. По мнению Б. Сарнова, автора книги «Наш советский новояз: Маленькая энциклопедия реального социализма», удвоение ВВП и страхование автогражданской ответственности являются такой же словесной оболочкой пустоты как советское «пятилетку в четыре года» (САРнов 2005). Особенно в последнее время появились многие слова и обороты, скрывающие за внешним наукообразованием не что иное, как явления экономического кризиса: дефолт, нулевые темпы роста, монетизация, волатильность рубля 'частое резкое значительное падение курса рубля', экономическая стагнация и т. д.

(6) Добавим, что по итогам 2015 года в Архангельской области нецелевое расходование бюджетных средств составило 8,9 млн. рублей или 1,4\% от общей суммы выявленных нарушений («Regnum», 02.06.2016).

(7) Именно в тот момент, когда политологи, торжествующе возвестили всему миру, что они наконец-то нашли особенную форму для российской демократии, а именно: суверенную демократию («Forum.msk.ru», 11.09.2015).

(8) На Острове мужества и скорби в столице открыли памятный камень в честь воинов, исполнявших интернациональный долг в Афганистане (Телеканал OHT, 28.05.2016).

(9) Поэтому непопулярная мера - повышение акцизов на бензин - была принята. [...] эта мера, хоть и нелюбимая водителями, позволит наполнить стремительно пустеющую казну государства и избежать еще более непопулярной меры - секвестирования бюджета («Новая трибуна», 07.06.2016). ${ }^{13}$

Что касается аббревиатур, то аббревиация остается продуктивным словообразовательным процессом и в наши дни, ср.: Центробанк, Госдума, ЦИК (Центризбирком), Генпрокурор, АО «Газпром», РАО ЕЭС, НДР, НДС, МЧС, $O P T, H T B$ и мн. др.

${ }^{13}$ Кстати, по мнению М. В. Горбаневского слово секвестр тоже является эвфемизмом, появившимся в результате нехватки бюджетных средств для покрытия расходов (ГоРБАНЕВСКий 2009: 6). 


\section{2. Десемантизация}

Как и раньше, в современном русском языке наблюдается активная десемантизация, т. е. использование слов и устойчивых словосочетаний с ослабленным или совершенно отсутствующим денотативным компонентом. К таковым А. Д. Васильев относит слово реформа; словосочетание программа реформ вследствие своей частотности стало устойчивым, однако его семантика остается туманной. Программа реформ воспринимается для россиян как звуковой комплекс, ничего не обозначающий так же, как стабилизация экономики, равноправное партнерство, секвестирование бюджета, реструктуризиия долга, успехи макроэкономики, депрессивная отрасль и т. д. (см. ВАСИЛЬЕВ 2000). ${ }^{14}$

В рамках десемантизации можно обсуждать и смену коннотаций. Особенно показательны примеры со сменой идеологических доминант, т. е. негативизация оценочности существительных коммунизм, сочиализм, Coветы, советский, совок и совковый, совковость, советикус и т. п. Наглядным примером служит употребление прилагательного советский. В советское время оно имело высоко положительную оценочность: советская молодежь, советский человек, советская наука, советский образ жизни. А теперь в нем возникло новое качественно-оценочное значение, которое впервые было отмечено в «Толковом словаре русского языка конца XXI века: Языковые изменения» под ред. Г. Н. Скляревской. Здесь слово имело помету «неодобр.» и формулировалось как 'свойственный чему-л. в СССР или кому-л., жившему в СССР’ (СКЛЯРЕВСКАЯ 1998: 596).

\section{3. Ритуальность}

Казалось бы, что современная политическая коммуникация гораздо менее ритуальна, чем в советские времена, однако язык продолжает использоваться в ритуальной функции, изменились лишь ритуальные правила и соответствующие им роли. Если в советский период, когда официально существовала одна партия, ритуальная коммуникация была ориентирована на поддержку властей и доминировала монологичная письменная речь, то современный ритуал имеет плюралистическую направленность: в нем существует несколько ролей «патриота», «центриста», «рыночника», «ортодоксального коммуниста», активиста движения зеленых и др. Согласно этому формируются некие правила игры. При оценке любого действия правительства правая

${ }^{14}$ Некоторые слова и словосочетания, включенные А. Д. Васильевым в список лексических фантомов постновояза, как нам представляется, не могут быть явлением десемантизации исключительно современного русского языка. Например, автор относит к разряду постновояза слова средний класс и миротворческий. Однако оба выражения являются кальками с английского языка (middle class и peace-keeping operation), и их расплывчатое употребление и употребление, противоположное первоначальному смыслу, наблюдается не только в русском, но во многих других языках, где для речевого обихода характерны подобные кальки. 
оппозиция характеризует его как ущемляющее права личности и экономическую свободу, а левая (национал-патриотическая и коммунистическая) критикует его как противоречащее национальным традициям, ведущее к обнищанию народа и отказу от социальных завоеваний советской эпохи (Чудинов 2006: 53).

Хотя современная политическая коммуникация плюралистическая, но она все же сохраняет специфический налет официозной стилистики; ее основная цель заключается в подтверждении своей социальной роли, и потому в ней не происходит дискуссии в подлинном смысле. С этой точки зрения современный постновояз, как и предшествующий советский вариант, противопоставлен диалогу как свободному обмену мнениями. В качестве примера приведем фрагмент разговора между сенатором и членом Высшего совета правящей партии «Единая Россия» Евгением Викторовичем Бушминым (Е. Б.) и бизнесменом Дмитрием Валерьевичем Потапенко (Д. П.): ${ }^{15}$

(10) Е. Б.: Поэтому Норвегия присоединилась к этим санкциям.

Д. П.: После того, как мы это сделали (ввели экономические санкции против Норвегии).

Е. Б.: И только... Еще раз это говорю... Норвегия присоединилась к этим санкциям и только после этого мы ввели ответные санкции... Норвегия присоединилась к этим санкииям до того, как мы ввели ответные санкции. Причем мы против Норвегии санкции не вводили. Мы ввели санкции против тех стран, которые присоединились к санкциям. Поэтому мы не могли ввести против Норвегии, если она не вводила санкции. Именно так звучала формулировка. Против тех стран, которые уже ввели санкции. Видите, значит, здесь неправильно.

Д. П.: (с иронией) Велика и могуча русская языка.

Е. Б.: Это, это русский язык, нормальный, нормальный.

Д. П.: Нет, это новояз чиновничий. Еще называется.

Е. Б.: (кричит, не давая говорить собеседнику) Нет, нет, ничего подобного! Те страны, которые ввели, подпадают под действие...

Д. П.: (пытается вставить слово). Ну, про экономику давайте.

Е. Б.: (опять срывается на крик) А если бы Норвегия не ввела, она бы не попала под санкции.

Д. П.: Ближе к экономике. Про продажи и про...

Как мы видим, представитель власти, чтобы не допустить дискуссии, использует прием механического повторения, прием «заезженной пластинки»: только в этом фрагменте сенатор механически повторяет одно и то же бюрократическое клише, не давая собеседнику вставить ни слова. Не случайно его собеседник охарактеризовал речь сенатора как «чиновничий новояз». В таких условиях абсолютно невозможно осуществление диалога, чего и добивается политик.

${ }^{15}$ Полное интервью см. https://www.youtube.com/watch?v=b-VaVGe3zYM. 
Итак, проведенный короткий анализ подтверждает, что риторические приемы, применяемые в современном политическом дискурсе, во многом напоминают черты советского новояза, что оправдывает характеристику современного политического подъязыка как постновояза.

\section{4. Выводы}

Язык политика всегда нацелен на борьбу за власть и удержание власти в своих руках в случае овладения ею. При этом политики часто пытаются завуалировать свои цели, используя различные риторические приемы, как номинализацию, эллипсис, метафоризацию и другие способы воздействия на сознание публики (СинЕокАя 2012). Соответственно, смысловая неопределенность и фантомность являются характерными признаками любого политического дискурса.

Учитывая эти факты, можно смело утверждать, что новояз - непременный атрибут языка власти как такового. И не только язык власти, но и любой язык содержит в себе отдельные элементы новояза, поскольку языку свойственна регулятивная функция. Просто со временем меняются конкретные слова и обороты, но риторические приемы повторяются. Итак, получается некий цикл: новояз постоянно возникает, затем становясь обыденным, уступает место новому новоязу в качестве старояза.

Данный тезис подтверждается проведенным анализом преемственности советского и постсоветского новояза. Последний стремится, как его оруэлловский прототип и его советский предшественник, активно реализовать такие приемы, как эвфемизацию, аббревиацию, десемантизацию, смену коннотаций, ритуализацию речевых актов и тем самым отдаляет слушателя от критического мышления.

Однако постновояз все-таки отличается от советского новояза. По мнению М. В. Горбаневского, советский новояз был сакральным, поскольку коммунизм для многих являлся некой религией, и, соответственно, употребление новояза носило ритуальный, сакральный характер. В то же время постновояз прежде всего призван фальсифицировать и завуалировать реальное положение вещей. Поэтому можно сказать, что последний более эвфемистичен, прагматичен, но менее сакрален (ГорБАнЕвский 2009b).

Все сказанное еще раз подтверждает многовековые тесные связи языка с властью, политикой в российском обществе. Недаром говорят, что слова в России - больше, чем слова.

\section{Литература}

БЕРДЯЕВ 1990 = БЕРДЯЕВ Н. А. Собрание сочинений. Т. 4. Духовные основы русской революиии. Париж, 1990.

БУРЛАЦКИЙ 1988 = БУРЛАЦКИй Ф. М. Новое мышление. Диалоги и суждения о технологической револючии и наших реформах. Москва, 1988. 
ВАСИЛЬЕВ $2000=$ ВАСИЛЬЕВ А. Д. Слово в эфире. Очерки новейшего словоупотребления в российском телевещании. Красноярск, 2000.

ВЕЖБИЦКАЯ 1993 = ВЕЖБИЦКАЯ А. Антитоталитарный язык в Польше. Bonpocы языкознания 1993/4: 107-125.

Винокур 1925 = Винокур Г. О. Культура языка. Очерки лингвистической технологии. Москва, 1925.

ГоломидовА $2009=$ ГоломидовА М. В. Вербальные символы СССР в современной коммерческой номинации. В кн.: КуПинА Н. А., МихАЙловА О. А. (ред.) Советское прошлое и культура настоящего. Екатеринбург, 2009. 332-348.

ГОРБАНЕВСКИЙ 2009а = ГОРБАНЕВСКИЙ М. В. О феномене нового новояза в России начала XXI в.: к постановке проблемы. В кн.: Социальные варианты языка VI. Maтериальи международной научной конференции. Нижний Новгород, 2009. 3-14.

ГОРБАНЕВСКИй 2009b = ГоРБАНЕВСКИй М. В. Риторика - форма существования слабой власти. Зачем современной политической элите потребовался новояз. Новая газета, 15 июня 2009 г. https://www.novayagazeta.ru/articles/2009/06/15/42493.

ГРИГОРЬЕВ 1998 = ГРИГОРЬЕВ А. Б. УТешенИе фиЛОЛОГИей. В Кн.: КЛЕМПЕРЕР В. LTI. Язык третьего рейха. Записная книжка филолога. Москва, 1998. 365-376.

ДАнн $2009=$ ДАнн Дж. А. Трансформация русского языка из языка советского типа в язык западного образца. В кн.: БудАЕВ Э. В., Чудинов А. П. Лингвистическая советология. Екатеринбург, 2009. 277-295.

Живов 1996 = Живов В. М. Язык и культура в России ХVIII века. Москва, 1996.

ЗЕмСКАЯ 1996а = ЗЕмСКАЯ Е. А. Новояз, newspeak, nowomova... Что дальше? В кн.: Дуличенко А. Д. (ред.) Русский язык конца ХХ столетия (1985-1995). Москва, 1996. 121-165.

ЗЕМСКАЯ $1996 \mathrm{~b}=$ ЗЕмСКАЯ Е. А. Клише новояза и цитация в языке постсоветского общества. Вопросы языкознания 1996/3: 23-31.

КРОНГАУз 2016 = КРОНГАУз М. Слово за слово: о языке и не только. Москва, 2016.

Крысин 2008 = Крысин Л. П. (ред.) Современный русский язык. Активныле процессы на рубеже веков XX-XXI веков. Москва, 2008.

КУЗИНА-МАЛЕРВЕЙН $2007=$ КУЗИНА Ю. И., МАЛЕРВЕЙН С. В. Деловая письменная коммуникаиия. Учебно-методическое пособие. Томск, 2007.

КупинА 1995 = КупинА Н. А. Тоталитарный язык. Екатеринбург-Пермь, 1995.

ЛЕйБОвич 1998 = ЛЕйБОвич О. Магия слова в советской культуре. В кн.: Русский язык в контексте современной культуры. Екатеринбург, 1998. 91-93.

ЛОТМАН-УСПЕНСКИЙ 1975 = ЛОТМАН Ю., УСПЕНСКИЙ Б. СПорЫ о языке в начале ХІХ в. как факт русской культуры. «Происшествие в царстве теней, или судьбина российского языка» - неизвестное сочинение Семена Боброва. Tруды по русской $u$ славянской филологии. Т. 24. Тарту, 1975. 168-322.

МихеЕв 1991 = МихеЕв А. В. Язык тоталитарного общества. Вестник Академии наук СССР 1991/8: 130-137.

НАм 2011 = НАм Хе Хен: Тенденция развития языка СМИ постсоветского периода: усиление личностного начала. Русский язык и литература 2011/4: 43-65.

НАм 2014a = НАм Хе Хен: Рефлексы новояза в современном русском языке. Studia Slavica Hung. 59 (2014): 377-392.

НАм 2014b = НАм Хе Хен: К исследованию советскости в современном русском дискурсе и языковой политике в постсоветском пространстве. Slavic Almanach. The South African Journal for Slavic, Central and Eastern European Studies 20 (2014): 86-102. 
НАм 2015 = НАм Хе Хен: Языковой пуризм и его социальный смысл: на примере языковой политики CCCP. В кн.: GREтснко Valerij, Kıм Soo Hwan, NonAKA Susumu (ed.): Far East, Close Russia. The Evolution of Russian Culture - A View from East Asia. Belgrade-Seoul-Saitama, 2015.

НОРМАН 1994 = НОРМАН Б. Ю. Лексические фантомы с точки зрения лингвистики и культурологии. В кн.: Язык и культура. III международная конференщия. Доклаdbl. Киев, 1994. 53-60.

Норман 2006 = НормАн Б. Ю. Игра на гранях языка. Москва, 2006.

Оруэлл 1989 = Оруэлл Дж. 1984 и эссе разных лет. Москва, 1989.

ПихуровА 2005 = ПихуровА А. А. Судьба советизмов в русском языке кониа XX-начала XXI века: на материале словарей и текстов. Дисс. ... канд. филол. наук. Саратов, 2005.

РЕЗАНОВА $2008=$ РЕЗАНОВА З. И. Трансформации советских стереотипов и мифологем в дискурсе региональных СМИ. Язык и культура 2008/3: 63-71.

РОМАненко 2000 = РомАненко А. П. Советская словесная культура: образ ритора. Саратов, 2000.

САРНОВ 2005 = САРНОВ Б. Наш советский новояз. Маленькая энияиклопедия реального соичиализма. Москва, 2005.

СИНЕОКАЯ 2012 = СИНЕОКАЯ Н. А. Характеристика политического дискурса. https:// science-education.ru/ru/article/view?id $=7695$.

СКЛЯРЕВСКАЯ 1998 = СКЛЯРЕВСКАЯ Г. Н. Толковой словарь русского языка конца ХХІ века. Языковые изменения. Санкт-Петербург, 1998.

ХАН-ПиРА 1994 = ХАН-ПиРА Э. И. Советский тоталитаризм и русский язык. В кн.: Нациионально-культурный компонент в тексте и в языке. Ч. 1. Минск, 1994. 16-18.

Чудинов 2006 = Чудинов А. П. Политическая лингвистика. Москва, 2006.

ШЕЙГАЛ 2005 = ШЕЙГАЛ Е. И. Семиотика политического дискурса. АДД. Санкт-Петербург, 2005.

BROŃSKI 1979 = BROŃSKI M. Totalitarny język komunizmu. Kultura 1979/12: 91-99.

Gasparov 2004 = Gasparov B. Identity in Language? In: Franklin S., Widdis E. (ed.) National Identity in Russian Culture. Cambridge, 2004. 132-148.

GŁOWIŃSKI 1991 = GŁOwIŃSKI M. Nowomowa po polsku. Warszawa, 1991.

SÉRIOT 1985 = SÉRIOT P. Analyse du discours politique soviétique. Paris, 1985.

VASSILEV 2011 = VASSILEV R. Newspeak in the language of politics in the post-totalitarian era. The case of Bulgaria. In: ANDREws E. (ed.) Legacies of Totalitarian Language in the Discourse Culture of the Post-Totalitarian Era. New York, 2011. 99-119. 